\title{
The effect of LMA Supreme and LMA ProSeal on intraocular pressure in children undergoing strabismus surgery
}

\author{
Neşe Türkyılmaz'1, Zehra Ipek Arslan², Özgül Altıntaş ${ }^{3}$, Mine Solak ${ }^{4}$
}

Objectives: It was shown that endotracheal intubation increases intraocular pressure higher than supraglottic airway devices. ${ }^{1}$ We aimed to compare the effects of insertion and removal of the LMA ProSeal and the LMA Supreme on intraocular pressure in pediatric patients undergoing elective strabismus surgery.

Methods: Fifty-four patients, ASA (American Society of Anaesthesiologists physical status) I-II, between the ages of 1-12 years were included in this study. After premedication with intravenous midazolam $(0,03 \mathrm{mg} / \mathrm{kg})$, anesthesia was induced with propofol and fentanyl. A neuromuscular blocker agent was not administered. Intraocular pressures, heart rate, systolic and diastolic blood pressures of the patients were recorded before and after the induction, after the insertion and three minutes after the insertion of the airway device, at the end of the surgical procedure and after the removal of the airway device. Development of oculocardiac reflex during the perioperative period and postoperative nausea and vomiting were recorded.

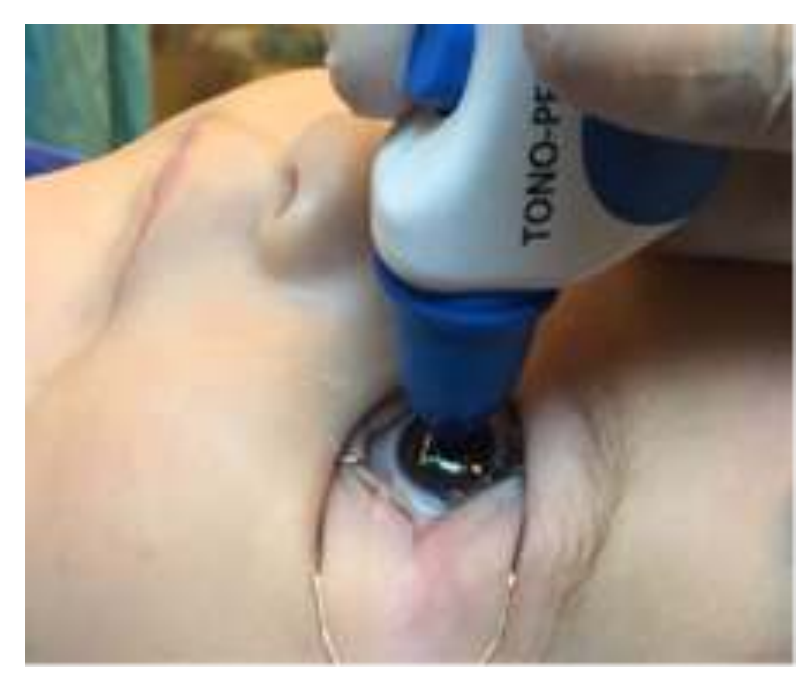

\begin{tabular}{|c|c|c|c|}
\hline & $\begin{array}{l}\text { LMA-P } \\
\qquad(n=27)\end{array}$ & $\begin{array}{l}\text { LMA-S } \\
(n=27)\end{array}$ & $\mathrm{p}$ \\
\hline $\begin{array}{c}\text { Age } \\
\text { (years) }\end{array}$ & $5,9 \pm 3,8$ & $5,5 \pm 2,8$ & 0,5 \\
\hline $\begin{array}{l}\text { Weight } \\
(\mathrm{kg})\end{array}$ & $20,3 \pm 7,8$ & $20,9 \pm 8,8$ & 1,0 \\
\hline $\begin{array}{c}\text { Gender } \\
\text { (F/M) }\end{array}$ & $13 / 14$ & $12 / 15$ & 1,0 \\
\hline ASA (I/II) & $23 / 4$ & $21 / 6$ & 0,7 \\
\hline
\end{tabular}

\begin{tabular}{|c|c|c|c|}
\hline & $\begin{array}{l}\text { LMA-P } \\
(n=27)\end{array}$ & $\begin{array}{l}\text { LMA-S } \\
(n=27)\end{array}$ & $\mathrm{p}$ \\
\hline $\begin{array}{l}\text { Duration of } \\
\text { surgery } \\
\text { (min) }\end{array}$ & $46,2 \pm 14,2$ & $50,0 \pm 18,2$ & 0,4 \\
\hline $\begin{array}{l}\text { Duration of } \\
\text { anesthesia } \\
\text { (min) }\end{array}$ & $61,6 \pm 14,9$ & $67,4 \pm 18,2$ & 0,21 \\
\hline
\end{tabular}

\begin{tabular}{|c|c|c|c|}
\hline & $\begin{array}{l}\text { LMA-P } \\
(n=27)\end{array}$ & $\begin{array}{l}\text { LMA-S } \\
(n=27)\end{array}$ & $\mathrm{p}$ \\
\hline $\begin{array}{l}\text { IOP } \\
\text { baseline }\end{array}$ & $13,4 \pm 4,2$ & $13,1 \pm 3,5$ & 0,7 \\
\hline $\begin{array}{l}\text { IOP after } \\
\text { anesthesia } \\
\text { induction }\end{array}$ & $11,4 \pm 3,8$ & $11,1 \pm 3,6$ & 0,8 \\
\hline $\begin{array}{l}\text { IOP after } \\
\text { SGA } \\
\text { insertion }\end{array}$ & $9,7 \pm 3,4$ & $12,6 \pm 3,9$ & $0,005^{\star}$ \\
\hline $\begin{array}{l}\text { IOP after } 3 \\
\text { minutes } \\
\text { SGA }\end{array}$ & $9,3 \pm 3,0$ & $10,3 \pm 3,5$ & 0,3 \\
\hline $\begin{array}{l}\text { IOP at the } \\
\text { end of } \\
\text { surgery }\end{array}$ & $9,5 \pm 3,6$ & $11,8 \pm 4,3$ & $0,04^{*}$ \\
\hline $\begin{array}{l}\text { IOP after } \\
\text { extubation }\end{array}$ & $9,8 \pm 3,1$ & $12,8 \pm 4,5$ & $0,008^{*}$ \\
\hline
\end{tabular}

Heart rates, systolic and diastolic blood pressure values were similar. No difference was found between the two groups related to the development of oculocardiac reflex and postoperative nausea and vomiting.Discussion: LMA Supreme raised the intraocular pressure more than that of LMA ProSeal after insertion, at the end of the surgical procedure and after the removal

References

1) İsmail SA, Bisher NA, Kandil HW, Mowafi HA, Atawia HA. Intraocular pressure and haemodynamic responses to insertion of the i-gel, laryngeal mask airway or endotracheal tube. Eur J Anaesthesiol 2011; 28: 443-48. 